\title{
Employing Virtual Reality (VR) Technology with Experiential Learning Perspective to Enhance Students' Learning Experience
}

\author{
Phoon Gar Chi, Muhammad Zaffwan Idris
}

To Link this Article: http://dx.doi.org/10.6007/IJARBSS/v11-i4/9712

DOI:10.6007/IJARBSS/v11-i4/9712

Received: 16 February 2021, Revised: 20 March 2021, Accepted: 05 March 2021

Published Online: 19 April 2021

In-Text Citation: (Chi \& Idris, 2021)

To Cite this Article: Chi, P. G., \& Idris, M. Z. (2021). Employing Virtual Reality (VR) Technology with Experiential Learning Perspective to Enhance Students' Learning Experience. International Journal of Academic Research in Business and Social Sciences, 11(4), 650-655.

Copyright: (c) 2021 The Author(s)

Published by Human Resource Management Academic Research Society (www.hrmars.com)

This article is published under the Creative Commons Attribution (CC BY 4.0) license. Anyone may reproduce, distribute, translate and create derivative works of this article (for both commercial and non-commercial purposes), subject to full attribution to the original publication and authors. The full terms of this license may be seen at: http://creativecommons.org/licences/by/4.0/legalcode

Vol. 11, No. 4, 2021, Pg. 650 - 655

Full Terms \& Conditions of access and use can be found at http://hrmars.com/index.php/pages/detail/publication-ethics 


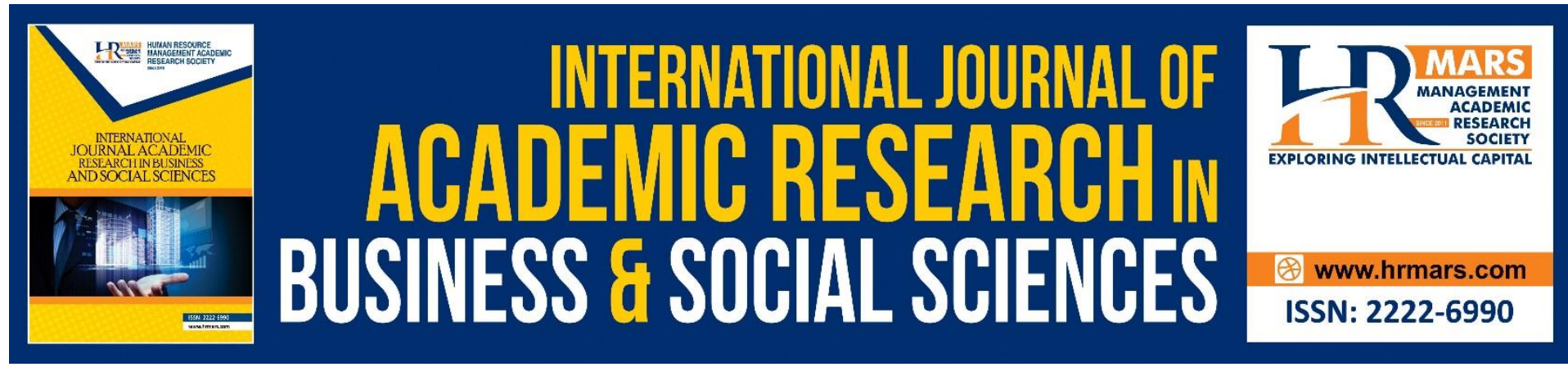

\title{
Employing Virtual Reality (VR) Technology with Experiential Learning Perspective to Enhance Students' Learning Experience
}

\author{
Phoon Gar Chi ${ }^{1}$, Muhammad Zaffwan Idris ${ }^{2}$ \\ ${ }^{1}$ Faculty of Communication and Creative Industries, Tunku Abdul Rahman University College \\ Kuala Lumpur, Malaysia, ${ }^{2}$ Faculty of Art, Computing and Creative Industry, Universiti \\ Pendidikan Sultan Idris, Perak, Malaysia \\ Email: phoongarchi@gmail.com
}

\begin{abstract}
The authors advocate to employ Virtual Reality (VR) with the application of experiential learning in order to enhance the students' learning experience. In modern world with diverse platforms for innovations and solutions, technology is shaping the future of education. New digital technology is used to improve the process of teaching and learning. Digital technology opens up a new space for learning where students are immerse through various forms of technological learning platforms, devices and applications. The application of digital technology in education can assist students to cope with different learning environment and improves students' learning efficiency. One of the innovative technologies for education is Virtual Reality (VR). VR has changed the way how students learn. VR allows us to bridge the gaps between educators and learners. VR can be used to stimulate a digital learning environment for educators and students to be together in the same room regardless of wherever they are physically and with digital representations of themselves. This paper will discuss the potential of integrating VR in education as one of the effective methods that can enhance students' learning experience.
\end{abstract}

Keywords: Digital Technology, Virtual Reality, Experiential Learning.

\section{Introduction}

The rapid and ongoing development of digital technologies continues to create new opportunities in improving the quality of our lives. The recent Covid-19 pandemic has escalated to process of adapting digital technologies in many areas including education. Education is the base for a thriving society, and the transfer of knowledge has been a top priority for civilizations since the very beginning. People are constantly looking for ways to make knowledge transfer more easily, more quickly, and more effectively. In the era of digital devices, we have an opportunity to enable better learning with technology (Montrieux et al., 2015). The Education Ministry has started moving towards the right direction to embrace digital learning. Surely, technology would be a boost to classroom instruction compared to analogue teaching, traditionally known as chalk-and-talk (The Star, 2017). Virtual reality technology has been widely proposed as a significant technological advance that can offer a 
novel form of education. VR seems to be the natural next steps for the evolution of education (Hu-Au at al., 2017). With VR, learners are inspired to discover for themselves. VR is useful not only for content consumption, but it is also great for content creation (Varnum, 2019). Hence, it allows user to create digital classroom including avatar as an alternative to the conventional classroom. The educational benefit of these applications is the active participation of students in learning process (Hamilton et al., 2021). This will help students boost their creativity and interact with students own imagination. This paper examines the use of VR tools to enhance significantly the learning experience. Thus, VR is useful in providing the learners with realism, interactivity and creation learning environment.

\section{Digital Technology in Education}

Diwan (2017) indicates that boredom can easily take place for today's learner as they are constantly looking to fill excitement from visual and auditory inputs. The implementation of digital technology provides learners to experience a visual element that can improves the connection between learning concepts and information effectively (Ilomaki \& Lakkala, 2018). The arrival of digital technology, the learning environment is changing (Leahy et al., 2019). Digital technology has opened the door for various new ways of learning, allows students the opportunity to learn in more meaningful ways ( $\mathrm{Ng}, 2016)$. Besides, prepared students to deal with the challenges of the future especially the Industrial Revolution 4.0 (IR4.0). Digital tools have impacted the traditional institution of a formal education, especially it increases the learning and interactivity of students (Hashim, 2018), as well as improved students learning efficiency (Teras et al., 2020).

\section{Virtual Reality (VR) in Education}

VR has found in education a new area in which to display its full potential (Sinclair \& Gunhouse, 2016). One of the most obvious benefits of VR is transforming lectures into immersive learning experiences, enabling lecturers to truly bring their subject to life (Radianti et al., 2019). The immersion in made-to-measure environments allows students to face learning experiences that maximize the use of all their senses (Serdyukov, 2017). VR can be used to enhance student learning and engagement. Kaminska et al. (2019) found that $82 \%$ of learners thought learning with VR was more engaging than learning from reading books and listening to lectures using overhead containing graphics or pictures. Furthermore, Allocoat and Von Muhlenen (2018) concurs that the situated nature of the learning process is very important and Mills (2020) emphasizes the connections it creates between knowledge, skill, and experience. One of the biggest advantages of such technology can be seen from the perspective of motivation, especially in terms of: (1) fun, interest and enjoyment; (2) engagement; (3) satisfaction; (4) willingness to learn; (5) positive attitude; (6) attention and (7) level of confidence (Gordon et al., 2016; Schott \& Marshall, 2018). Hence, VR has created a new way of learning and making learning experience more fun, engaging and interest about the subject (Jones, 2020).

\section{Experiential Learning}

Experiential Learning (ExL) is the process of learning through experience and is more specifically as learning through reflection of doing thing (Kolb \& Kolb, 2018). Experiential learning focuses on the learning process for the individual (McCarthy, 2016). The trend toward experiential learning also stems from changing student expectations in the classroom, in a kind of customer-led revolution in communication quality (Oke \& Fernandes, 2020). 
Experiential learning focuses on learners reflecting on their experience of doing something, so as to gain conceptual insight as well as practical expertise (Bates, 2015). Learning only has good effects when learners have the desire to absorb the knowledge (Leal-Rodriguez \& Albort-Morant, 2019). Therefore, experiential learning requires the showing of directions for learners, learners learn by doing them.

In digital age, students today are rarely satisfied with a one-size-fits-all classroom experience, particularly if it consists solely of the droning lecturer, and are justifiably looking for an enhanced learning experience from the university (Rinehardt-Cline, 2018). Bartle (2015) claims that experiential learning activities helps students find meaning in their experiences. Experiential learning entails a hands-on approach to learning that moves away from just the teacher at the front of the room imparting and transferring their knowledge to students (Austin \& Rust, 2015). Hence, learning an experience that moves beyond the classroom and strives to bring a more involved way of learning (Zhai et al., 2017).

\section{Conclusion}

In education, new digital and virtual technologies including VR are used to improve the process of learning, hence the rise of Cybergogy as one of the learning strategies. Digital technology offerings educators a new way to interact with the students by using suitable applications for learning (Hussein \& Natterdal, 2015). The use of digital technological tools such as VR is increasing rapidly in all fields, especially in education, which has moved from basic tools such as pen, pencil, and books, to more advance tools such as digital devices and software applications. Interactive technology that can embedded in VR classroom is imperative in order to impart knowledge and understanding (Alfalah, 2018) as well as to increase students' engagement. VR technology has a positive impact in the areas of inspiring wonder and curiosity, developing new creative skills and offering authentic 'learn by doing' experiences (Bailenson, 2018). In conclusion, with the application of VR in education, in many ways would help students to develop the knowledge and skills needed in a digital age and offers advantages in securing job opportunities.

\section{Corresponding Author}

Muhammad Zaffwan Idris

Faculty of Art, Computing and Creative Industry, Universiti Pendidikan Sultan Idris

Email: zaffwan@fskik.upsi.edu.my

\section{References}

Alfalah, S. F. (2018). Perceptions toward adopting virtual reality as a teaching aid in information technology. Education and Information Technologies, 23(6), 2633-2653.

Allcoat, D., \& von Mühlenen, A. (2018). Learning in virtual reality: Effects on performance, emotion and engagement. Research in Learning Technology, 26.

Austin, M. J., \& Rust, D. Z. (2015). Developing an Experiential Learning Program: Milestones and Challenges. International Journal of Teaching and Learning in Higher Education, 27(1), 143-153.

Bailenson, J. (2018). Experience on demand: What virtual reality is, how it works, and what it can do. WW Norton \& Company.

Bartle, E. (2015). Experiential learning: an overview. Institute for Teaching and Learning Innovation. Australia: The University Of Queensland.

Bates, A. T. (2015). 3.6 Experiential learning: learning by doing (2). Teaching in a Digital Age. 
Gordon, N., Grey, S., \& Brayshaw, M. (2016). Motivating and engaging students through technology.

Hamilton, D., McKechnie, J., Edgerton, E., \& Wilson, C. (2021). Immersive virtual reality as a pedagogical tool in education: a systematic literature review of quantitative learning outcomes and experimental design. Journal of Computers in Education, 8(1), 1-32.

Hashim, H. (2018). Application of technology in the digital era education. International Journal of Research in Counseling and Education, 2(1), 1-5.

Hussein, M., \& Nätterdal, C. (2015). The benefits of virtual reality in education-A comparision Study.

Ilomäki, L., \& Lakkala, M. (2018). Digital technology and practices for school improvement: innovative digital school model. Research and practice in technology enhanced learning, 13(1), 1-32.

Jones, B. D. (2020). Motivating and Engaging Students Using Educational Technologies. In Handbook of Research in Educational Communications and Technology (pp. 9-35). Springer, Cham.

Kaminska, D., Sapinski, T., Wiak, S., Tikk, T., Haamer, R. E., Avots, E., ... \& Anbarjafari, G. (2019). Virtual reality and its applications in education: Survey. Information, 10(10), 318.

Kolb, A., \& Kolb, D. (2018). Eight important things to know about the experiential learning cycle. Australian educational leader, 40(3), 8.

Leahy, S. M., Holland, C., \& Ward, F. (2019). The digital frontier: Envisioning future technologies impact on the classroom. Futures, 113, 102422.

Leal-Rodriguez, A. L., \& Albort-Morant, G. (2019). Promoting innovative experiential learning practices to improve academic performance: Empirical evidence from a Spanish Business School. Journal of Innovation \& Knowledge, 4(2), 97-103.

McCarthy, M. (2016). Experiential learning theory: From theory to practice. Journal of Business \& Economics Research (JBER), 14(3), 91-100.

Mills, N. (2020). 11 Engagement and Immersion in Virtual Reality Narratives. Student engagement in the language classroom.

Ng, W. (2016). NEW DIGITAL TECHNOLOGY IN EDUCATION. Springer International PU.

Oke, A., \& Fernandes, F. A. P. (2020). Innovations in teaching and learning: Exploring the perceptions of the education sector on the 4th industrial revolution (4IR). Journal of Open Innovation: Technology, Market, and Complexity, 6(2), 31.

Radianti, J., Majchrzak, T. A., Fromm, J., \& Wohlgenannt, I. (2020). A systematic review of immersive virtual reality applications for higher education: Design elements, lessons learned, and research agenda. Computers \& Education, 147, 103778.nic chemistry instruction. Virtual Reality, 23(4), 363-373.

Rinehardt-Cline, M. (2018). The effects of blended learning on student achievement, interaction levels, and online readiness skills in the high school social studies classroom. Unpublished doctoral dissertation). Charlotte, NC: University of North Carolina.

Schott, C., \& Marshall, S. (2018). Virtual reality and situated experiential education: A conceptualization and exploratory trial. Journal of computer assisted learning, 34(6), 843-852.

Serdyukov, P. (2017). Innovation in education: what works, what doesn't, and what to do about it?. Journal of Research in Innovative Teaching \& Learning, 10(1), 4-33. 
Sinclair, B., \& Gunhouse, G. (2016). The promise of virtual reality in higher education. EDUCAUSE Review. Retrieved from http://er. educause. edu/articles/2016/3/thepromise-of-virtual-reality-in-higher-education.

Teräs, M., Suoranta, J., Teräs, H., \& Curcher, M. (2020). Post-Covid-19 education and education technology 'solutionism': A seller's market. Postdigital Science and Education, 2(3), 863-878.

Zhai, X., Gu, J., Liu, H., Liang, J. C., \& Tsai, C. C. (2017). An Experiential Learning Perspective on Students' Satisfaction Model in a Flipped Classroom Context. Educational Technology \& Society, 20(1), 198-210. 